\title{
Research on Manufacturing Processes and Dynamic Balance Test of Motorized Spindle Shaft
}

\author{
Chilan Cai*, Yafei He, Jian Wei, Ning Li, Hongfeng Zhu \\ College of Engineering \\ Shanghai Second Polytechnic University \\ Shanghai 201209, P. R. China \\ *clcai@sspu.edu.cn, yfhei@sspu.edu.cn, ritterns@hotmail.com, lining@sspu.edu.cn, hfzhu@sspu.edu.cn
}

\begin{abstract}
The shaft is the core transmission part of the motorized spindle. Based on the mechanical performance requirements and assembly requirements with other parts, this paper did the structural analysis on the shaft, and developed a set of high efficient manufacturing processes, including processing steps, heat treatment technology and cutting tools selection, etc. This paper also verified the feasibility of these processes with real shaft processing, did the unbalance detection at the dynamic balancing machine, then reduced the dynamic unbalance with some improvement measures.
\end{abstract}

Keywords-structural analysis; manufacturing processes; heat treatment; CNC; dynamic balance

\section{INTRODUCTION}

High-speed machining technology is one of the four modern advanced manufacturing technologies, which has the main features of high cutting speed, high feed speed, and high machining precision. It is one of the high-tech technologies that leads to second manufacturing technology revolutionary leap [1]. High-speed motorized spindle is one of the core components to achieve high-speed machining, and equipped at most high-speed machine tools [2]. Shaft is the main rotation part of the motorized spindle and the manufacturing precision of the shaft will directly affect the spindle ultimate precision. The requirements of geometric tolerances and dimensional accuracy of finished shaft are very high. This paper designed a motorized spindle for high-speed machining center. The shaft structure was designed as an elongated hollow shaft, and the broach system was installed inside. It used separate structure, and the front end of the shaft separated from the rest of the shaft, as shown in Fig. 1. During operation, the shaft will withstand stress and centrifugal force and other cutting complex stress, and has high assembly accuracy requirements with other multiple components, therefore its processing technology and precision are the key issues.

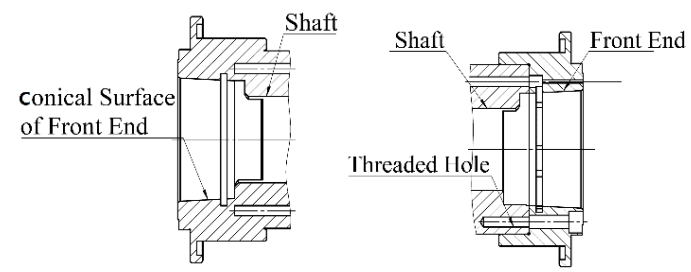

(a) Integrated shaft (b) Assembly drawing of shaft and front end

Fig.1 Relation of shaft and front end
Firstly, this paper did the structural analysis of shaft, considering the dimension, position accuracy requirements, and assembly requirements with other parts. Secondly, it studies the manufacturing processes of shaft. Then it designed a feasible and efficient processing scheme, and through the actual shaft processing to verify the feasibility of the manufacturing processes.

\section{SHAFT STRUCTURE ANALYSIS AND PROCESSING PROBLEMS}

The assembly schematic diagram of shaft with other parts is shown in Fig. 2, the shaft 1 is a hollow shaft and broach institutions with tool clamping function is installed inside. The shaft and the shaft front end 2 are connected by a bolt, to locate the tool installation. Between of them is the inner spacer 3, with several uniform arrangement threaded holes inside, to do the dynamic balance adjustment during motorized spindle assembly. Next part is the front bearing 4 that interference fit with the shaft. Central part of shaft is connected with motor rotor 5 through the rotor heating or shaft cooling process, and the rear end is the back bearing 6. As there are many high precision assembly requirements on the shaft and other parts, the processes need to consider the shaft dimensional and geometric tolerance requirements, and also the assembly requirements of shaft and other parts. So it is necessary to adjust the manufacturing processes to improve the machining accuracy and surface quality of the shaft.

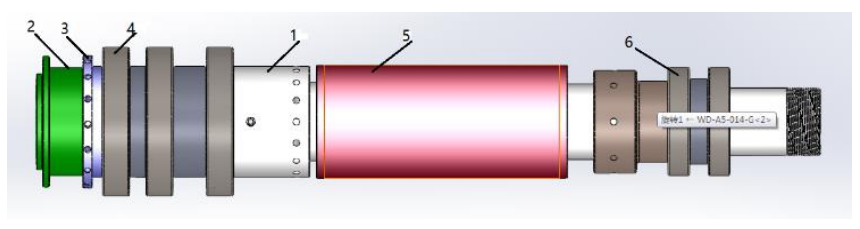

Fig. 2 Assembly schematic diagram of shaft with other parts(1-shaft, 2shaft front end, 3-front end inner spacer, 4-front bearing, 5-motor rotor, 6back bearing)

During the high-speed machining process, the broach institution directly delivers the complex cutting stress to the shaft. In order to reduce the shaft deformation, extend service life time, and ensure the machine's high precision, the shaft blank is required to do swaging process and grain refinement, to make the material structure more closely and improve the material properties. During the machining process, it necessary to choose the right heat treatment process, and 
optimize the materials, to improve the mechanical properties of strength and wear resistance, etc.

\section{MANUFACTURING PROCESSES ANALYSIS AND DESIGN}

Shaft part drawing is shown in Fig. 3. The machining characteristics are as following: stepped cylindrical surface, end face, internal through hole, front-end key, rear end inner and outer thread, gas pores, and threaded hole. This section will focus on above processing characteristics, to analyze machining process and design a reasonable machining solution.

\section{A. Material Selection and Heat Treatment Process}

According to Fig. 3, the total length of the shaft is $562 \mathrm{~mm}$, the maximum outer diameter is $\emptyset 82 \mathrm{~mm}$, and maximum bore diameter is $\varnothing 41.6 \mathrm{~mm}$. Considered the mechanical property requirements and processing economy requirements, this shaft adopted material $38 \mathrm{CrMoAl}$, blank forging process and grain refinement.

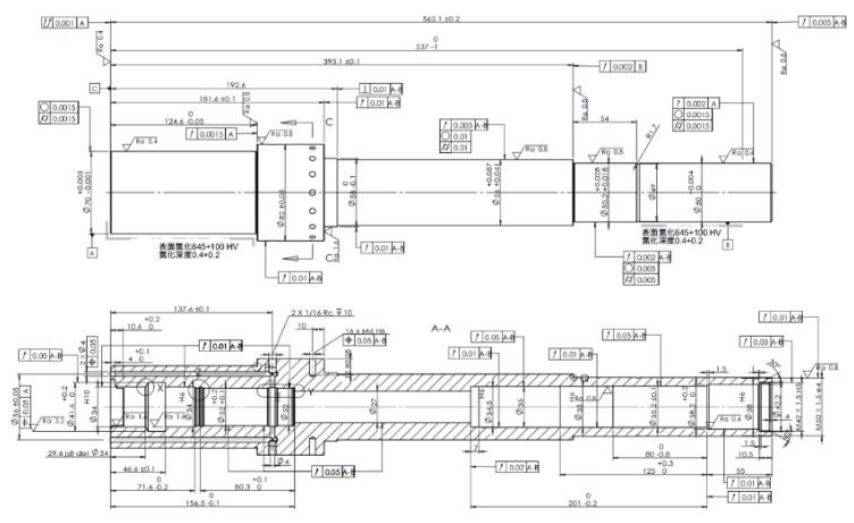

Fig. 3 Shaft part drawing

Since the deviation of the forging material is big, it should increase the size of the rough material, so the cylindrical blank of $\varnothing 100 \times 600$ is selected. After forging, the materials will have high surface hardness and big internal stress. It's difficult to do cutting process, and need to do quenching, so as to eliminate the internal stress, arrange the internal structure, soften the material and reduce the surface hardness [3].

Metal cutting is the process that the cutting material layer is squeezed by the force of cutting blade and front rake, then generate sliding deformation along the shear plane, and into the chips, so as to format the machined surface [4]. Therefore, in the cutting process, cutting stress will be produced inside the material. After each step of shaft machine process, it need to choose the right heat treatment processes, to reduce the shaft material internal stress, and also do surface nitriding treatment to improve shaft part strength, wear resistance, and other mechanical properties.

\section{B. Cutting tool selection}

According to the required shaft machining features, following tools are selected [5], as shown in Table 1.

\section{Shaft Processing Stages}

Routing arrangements must consider parts design requirements, production type and the actual production capacity, etc. According to the technical requirements of shaft, combined with the current processing resources, following process routes were designed [6]:

\section{1) Blank pre-processing stage}

Through forging process, the mechanical properties of the shaft material was improved and optimized. At the same time the forging will lead to big internal stress and high hardness, so it is difficult to cut material. It is necessary to do quenching and tempering, to reduce the internal stress and material hardness, soften material and get stable mechanical properties.

TABLE 1 TOOL USAGE LIST

\begin{tabular}{|c|c|c|c|}
\hline No. & Tool Type & $\begin{array}{c}\text { Tool angle } \\
\text { (diameter) }\end{array}$ & tool R angle (length) \\
\hline 01 & plane turning & 90 & $0.8(0.4 、 0.2)$ \\
\hline 02 & Cylindrical turning & 90 & $0.8(0.4,0.2)$ \\
\hline 03 & $\begin{array}{c}\text { Internal boring } \\
\text { cutter }\end{array}$ & 90 & $0.8(0.4 、 0.2)$ \\
\hline 04 & $\begin{array}{c}\text { Straight shank twist } \\
\text { drill }\end{array}$ & 20 & 300 \\
\hline 05 & $\begin{array}{c}\text { Taper shank twist } \\
\text { drill }\end{array}$ & 30 & 150 \\
\hline 06 & $\begin{array}{c}\text { Long straight shank } \\
\text { twist drill }\end{array}$ & $\varnothing \mathbf{4}$ & 50 \\
\hline 07 & Vertical mills & $\varnothing \mathbf{4}$ & \\
\hline 08 & Grinding wheel & \multicolumn{2}{c|}{} \\
\hline
\end{tabular}

The shaft is an elongate shaft. During the cutting processing, due to the cantilever principle, the parts of the shaft away from the fixed end will have bending deformation, so that generate cutter relieving phenomenon, and affect the overall precision. Therefore, during processing, one side of shaft is clamped, and other side is pushed, which convert cantilever to a simply supported beam, to reduce shaft deflection and reduce stress deformation [7].

During pre-processing stage, firstly quench and temper blank material, then select a lathe with the larger center hole to clamp blank, cut the end face, and drill center hole, so as to prepare for rough machining.

\section{2) Turning stage of shaft}

One end of the blank material is clamped by the Jaw chuck, and the other end is supported by the top center hole with tailstock, to reduce the tremor during turning process. Firstly, one end of the cylindrical surface with the step is cut, and then process another end with the same clamping manner. After rough processing steps, bilateral outer margin is $3 \mathrm{~mm}$, length margin is $3 \mathrm{~mm}$. As the cylindrical using high efficient rough processing strategy, the cutting parameters are large, so the resulting work will have greater internal cutting stress. After a period of time, the work will naturally release internal stresses, resulting in local deformation and impacting on dimensional precision. So it is necessary to do heat treatment of the work piece, and prompt the release of internal stress. Here high temperature tempering process is used. The workpiece is firstly heated to $600^{\circ} \mathrm{C}$, and then placed in the 
air naturally cooled down to room temperature. After the process the workpiece material can be more uniform, and mechanical properties of the workpiece is improved.

\section{3) Hole drilling and boring stage}

Since the shaft is an elongated shaft, the axial dimension is much larger than the range of boring drills and lathes, and therefore the inner hole processing requires two reverse fixture intact. In the two clamping process, it will generate repeat positioning errors, influence the straightness of the bore axis, result in poor concentricity between cylindrical and bore, and increase the dynamic unbalance of the shaft. Therefore, before the inner hole machining, grinding process is used to ensure that the circular degree and cylindricity of the cylindrical, to act as a reference for next step processing. At the same time, the use of the center frame as shown in Fig. 4 aims to increase anchor points, reduce the span of the shaft, reduce its deflection, to avoid distortion deformation of the shaft. In addition, during the usage of the center frame, the three rubber fulcrum should be covered by appropriate lubricant and build up a film between the support and the workpiece, to reduce wear and tear of the support.
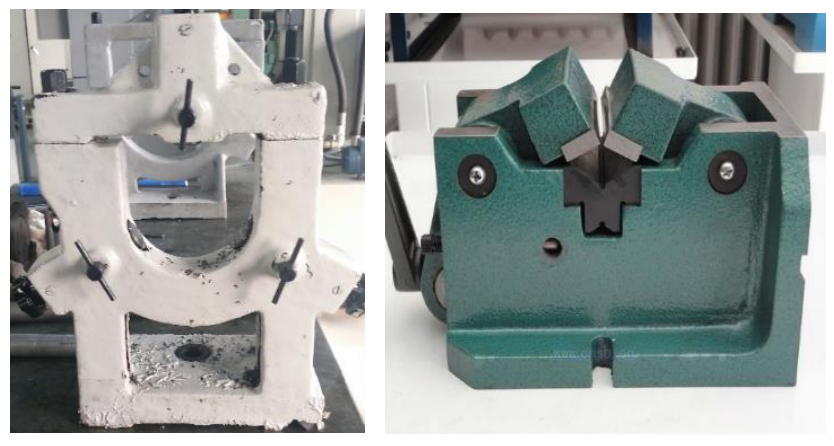

Figure 4 Center frames V-Pliers

At the inner hole machining stage, firstly install the drill on the tailstock, rotate shaft, drill slowly into the shaft with a small diameter drill, and then remain drilling with large diameter drill, finally use a long boring cutter to machine the inner hole.

According to the shaft design requirements, the process of hole machining is separated into two steps. And during the clamping of shaft, each step need to do some adjustment to keep the accuracy of circular degree. The machine process is designed according to shaft drawing. The bore bilateral margin is $1.2 \mathrm{~mm}$. After that, the shaft will be processed with second high-temperature tempering to increase performance and improve the material structure.

\section{4) Milling stage}

During key milling and deep hole drilling, V-shaped flat jaw as shown in Figure 4 is used, which is mounted on the machine table. In addition, the cutting depth should be adjusted at the axial direction, to generate the axial direction margin $0.3 \mathrm{~mm}$. For irregular shape outline, CAM technology is used to improve production efficiency. At the same time, the manual of Machining Technology is used as reference [8] to choose reasonable machining parameters, and prevent the emergence of broken drill during deep hole drilling process.

\section{5) Grinding stage}

Surface nitriding treatment is the process that put steel parts into a reactive nitrogen environment for a certain time, to make the nitrogen atom penetrated into the steel surface. In order to increase the shaft surface hardness, wear resistance, fatigue resistance, corrosion and seizure resistance, this project uses the method of partial nitriding for shaft heat treatment, and corresponding areas that not need nitriding are protected by medicinal liquid. Then both ends and outer surface of the shaft are grinded to satisfy the tolerance. After grinding, the shaft, rotor and rotor washer are heated to fit together, as shown in Fig. 5.

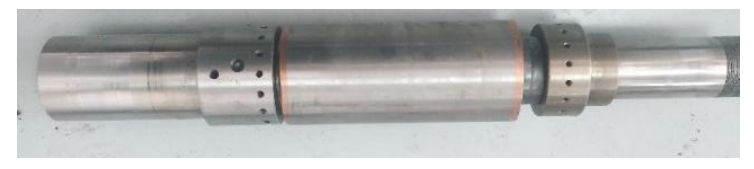

Fig. 5 Shaft assembly photo

As shown in Fig. 6, the shaft assembly is supported by two $\mathrm{V}$-shaped pads. There is a leather with butter located between the V-shaped pad and pressed block, and they are pressed together. The shaft inner hole is grinded with the size of the allowance $0.08 \mathrm{~mm}$, and other dimensions were machined according to the drawings. In the grinding process, it's necessary to choose the right cutting parameters to improve production efficiency and assure process quality.

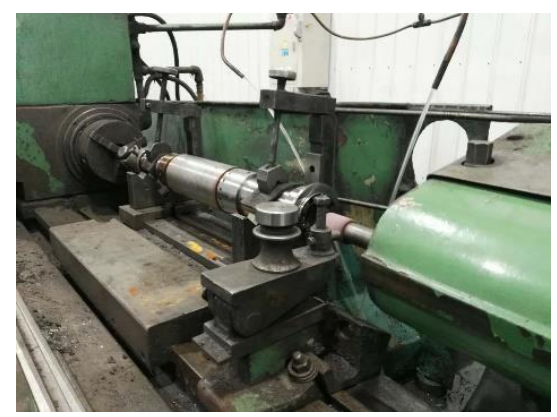

Fig. 6 Shaft assembly grinding

In the grinding process, the heat is generated by the friction between the grinding wheel and the part surface, and be took away partly by cutting liquid, and partly by parts. Since the metal thermal deformation, after the completion of each grinding process, it is required to stop the processing and allow the work piece natural cool down. After it cool down to standard measured temperature, then continues the next step. This cooling down process can avoid the impact of the thermal deformation on the measurement results.

To grind the interface between the shaft and broach institution, the shaft front end and the shaft are connected by bolts, and fixedly mounted on a V-shaped pad. In the grinding process, as shown in Fig. 7(a), standard shank and special designed gage are used, to ensure the dimensional accuracy of the workpiece. In the measurement process, as shown in Fig. 7(b), the shank taper surface is painted with color, and then the shank is inserted into the hole, rotates one circle, and then observes the coloring rate of the hole taper surface. According 
to the national design standard of motorized spindle for machining center, the coloring rate must be more than $85 \%$.

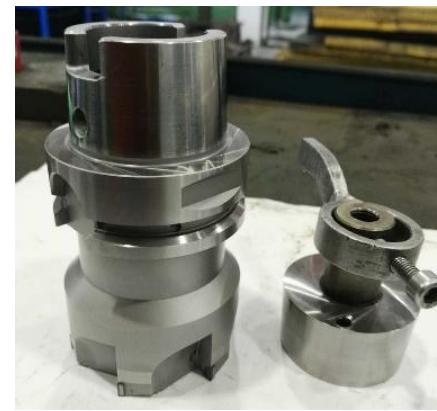

(a) Shank and Gage

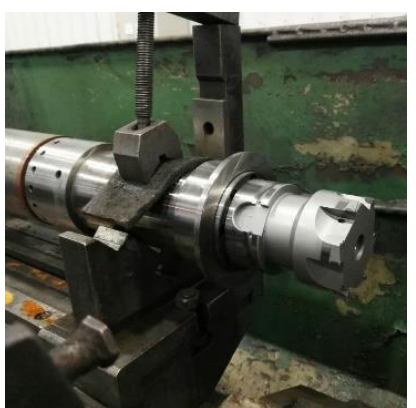

(b) Gage usage schematic
Fig. 7 Shaft interface size grinding

Based on the above analysis of process route, this paper developed a reasonable shaft manufacturing processes, as shown in Table 2.

TABLE 2 SHAFT MANUFACTURING PROCESSES

\begin{tabular}{|c|c|c|c|c|}
\hline No. & Process name & Equipment & Cutting tool & Measuring \\
\hline 1 & Forging blank & $\begin{array}{c}\text { Forging } \\
\text { machines }\end{array}$ & & \\
\hline 2 & $\mathrm{~T} 235$ & & & \\
\hline 3 & $\begin{array}{l}\text { Cut end surface, } \\
\text { drill center hole, } \\
\text { lathe blank } \\
\text { cylindrical } \emptyset 82, \\
\text { the total length is } \\
562.1, \text { margin is 5, } \\
\text { lathe cylindrical } \\
\varnothing 70, \text { length is } \\
124.6, \text { the margin } \\
\text { of radius is } 3\end{array}$ & $\begin{array}{c}\text { Lathe } \\
\text { CW6263B }\end{array}$ & $\begin{array}{l}90^{\circ} \text { facing } \\
\text { tool, } \\
90^{\circ} \\
\text { external } \\
\text { turning } \\
\text { tool, center } \\
\text { drill }\end{array}$ & $\begin{array}{l}\text { Vernier } \\
\text { Calipers }\end{array}$ \\
\hline 4 & $\begin{array}{l}\text { Turn round shaft, } \\
\text { cut end surface, } \\
\text { drill center hole, } \\
\text { lathe blank } \\
\text { cylindrical } \emptyset 58, \\
\text { length is } 380.5 \text {, } \\
\text { lathe blank } \\
\text { cylindrical } \emptyset 56 \text {, } \\
\text { length is } 369.5 \text {, } \\
\text { lathe blank } \\
\text { cylindrical } \emptyset 50 \text {, } \\
\text { length is } 143.9, \\
\text { the margin of the } \\
\text { radius is } 3\end{array}$ & $\begin{array}{c}\text { Lathe } \\
\text { CW6263B }\end{array}$ & $\begin{array}{l}90^{\circ} \text { facing } \\
\text { turning } \\
\text { tool, } \\
90^{\circ} \\
\text { external } \\
\text { turning } \\
\text { tool, center } \\
\text { drill }\end{array}$ & $\begin{array}{l}\text { Vernier } \\
\text { Calipers }\end{array}$ \\
\hline 5 & Tempering & & & \\
\hline 6 & $\begin{array}{l}\text { Cut end surface, } \\
\text { lathe blank } \\
\text { cylindrical } \emptyset 82, \\
\text { the total length is } \\
181.6, \text { margin is } 3 \text {, } \\
\text { lathe cylindrical } \\
\varnothing 70, \text { length is } \\
124.6, \text { the margin } \\
\text { of the radius is } 1.8\end{array}$ & CAK6150D & $\begin{array}{l}90^{\circ} \text { facing } \\
\text { turning } \\
\text { tool, } \\
90^{\circ} \text { external } \\
\text { turning } \\
\text { tool, } \\
\text { apex }\end{array}$ & $\begin{array}{c}\text { Vernier } \\
\text { Calipers, } \\
\text { Outside } \\
\text { Micrometer }\end{array}$ \\
\hline 7 & $\begin{array}{l}\text { Turn round shaft, } \\
\text { cut end surface, } \\
\text { lathe blank }\end{array}$ & CAK6150D & $\begin{array}{l}90^{\circ} \text { facing } \\
\text { turning } \\
\text { tool, }\end{array}$ & \\
\hline
\end{tabular}

\begin{tabular}{|c|c|c|c|c|}
\hline & $\begin{array}{l}\text { cylindrical } \emptyset 58, \\
\text { length is } 380.5, \\
\text { lathe blank } \\
\text { cylindrical } \emptyset 56, \\
\text { length is } 369.5, \\
\text { lathe blank } \\
\text { cylindrical } \emptyset 50 \text {, } \\
\text { length is } 143.9 \text {, } \\
\text { the margin of the } \\
\text { radius is } 1.8\end{array}$ & & $\begin{array}{l}90^{\circ} \text { external } \\
\text { turning } \\
\text { tool, } \\
\text { apex }\end{array}$ & $\begin{array}{c}\text { Vernier } \\
\text { Calipers, } \\
\text { Outside } \\
\text { Micrometer }\end{array}$ \\
\hline 8 & $\begin{array}{l}\text { Build center } \\
\text { frame, adjust } \\
\text { cylindrical, runout } \\
\text { tolerance is } 0.02 \text {, } \\
\text { grinding outer } \\
\text { cylindrical } \emptyset 70 \text {, } \\
\varnothing 82, \emptyset 58, \emptyset 56, \\
\varnothing 50, \text { the margin } \\
\text { of the radius is } 1\end{array}$ & $\begin{array}{c}\text { MK1632X1 } \\
000\end{array}$ & $\begin{array}{l}\text { cylindrical } \\
\text { grinding } \\
\text { wheel A46, } \\
\text { the center } \\
\text { frame }\end{array}$ & $\begin{array}{l}\text { Length } \\
\text { Micrometer } \\
\text { Outside } \\
\text { Micrometer }\end{array}$ \\
\hline 9 & $\begin{array}{l}\text { Cut end surface, } \\
\text { the margin of total } \\
\text { length is } 1, \text { drill } \\
\text { center hole } \emptyset 20 \text {, } \\
\text { rough boring } \\
\text { center hole } \emptyset 27 \text {, } \\
\varnothing 34.5, \emptyset 38, \text { the } \\
\text { margin of all } \\
\text { radius is } 1\end{array}$ & CAK6150D & $\begin{array}{c}90^{\circ} \text { facing } \\
\text { turning } \\
\text { tool, } \\
\text { straight } \\
\text { shank twist } \\
\text { drill, center } \\
\text { hole boring } \\
\text { tool, center } \\
\text { frame } \\
\end{array}$ & $\begin{array}{c}\text { Calipers, } \\
\text { Inside } \\
\text { Micrometer } \\
\text {, } \\
\text { Depth } \\
\text { Gauges }\end{array}$ \\
\hline 10 & $\begin{array}{l}\text { Turn round shaft, } \\
\text { cut end surface, } \\
\text { drill center hole } \\
\varnothing 20, \text { rough boring } \\
\text { center hole } \emptyset 34, \\
\varnothing 41.6, \emptyset 32, \emptyset 27, \\
\text { the margin of all } \\
\text { radius is } 1\end{array}$ & CAK6150D & $\begin{array}{c}90^{\circ} \text { facing } \\
\text { turning } \\
\text { tool, } \\
\text { straight } \\
\text { shank twist } \\
\text { drill, center } \\
\text { hole boring } \\
\text { tool, center } \\
\text { frame } \\
\end{array}$ & $\begin{array}{c}\text { Calipers, } \\
\text { Inside } \\
\text { Micrometer } \\
\text {, } \\
\text { Depth } \\
\text { Gauges }\end{array}$ \\
\hline 11 & Tempering & & & \\
\hline 12 & $\begin{array}{l}\text { Cut end surface, } \\
\text { the margin of total } \\
\text { length is } 0.5 \text {, lathe } \\
\text { cylindrical } \emptyset 70, \\
\emptyset 82 \text {, the margin } \\
\text { of all radius is } 0.4\end{array}$ & CAK6150D & $\begin{array}{l}90^{\circ} \text { facing } \\
\text { turning } \\
\text { tool, } \\
90^{\circ} \text { external } \\
\text { turning tool }\end{array}$ & $\begin{array}{c}\text { Calipers, } \\
\text { Outside } \\
\text { Micrometer }\end{array}$ \\
\hline 13 & $\begin{array}{l}\text { Turn round shaft, } \\
\text { cut end surfaces, } \\
\text { lathe cylindrical } \\
\emptyset 58, \emptyset 56, \emptyset 52 \text {, } \\
\text { the margin of all } \\
\text { radius is } 0.4\end{array}$ & CAK6150D & $\begin{array}{c}90^{\circ} \text { facing } \\
\text { tool, } \\
90^{\circ} \text { external } \\
\text { turning tool }\end{array}$ & $\begin{array}{c}\text { Calipers, } \\
\text { Outside } \\
\text { Micrometer }\end{array}$ \\
\hline 14 & $\begin{array}{l}\text { Build center } \\
\text { frame, Runout is } \\
0.02 \text {, rough } \\
\text { grinding end } \\
\text { faces, margin of } \\
\text { total length is } 0.3\end{array}$ & $\begin{array}{c}\text { MK1632X7 } \\
1000\end{array}$ & $\begin{array}{l}\text { cylindrical } \\
\text { grinding } \\
\text { wheel A46 }\end{array}$ & $\begin{array}{c}\text { Depth } \\
\text { Gauges }\end{array}$ \\
\hline 15 & $\begin{array}{l}\text { Grinding outer } \\
\text { cylindrical } \emptyset 70 \text {, } \\
\varnothing 82, \emptyset 58, \emptyset 56 \text {, } \\
\varnothing 50 \text {, the margin } \\
\text { of radius is } 0.2\end{array}$ & $\begin{array}{c}\text { MK1632X1 } \\
000\end{array}$ & $\begin{array}{l}\text { cylindrical } \\
\text { grinding } \\
\text { wheel A46 }\end{array}$ & $\begin{array}{c}\text { Calipers, } \\
\text { Outside } \\
\text { Micrometer }\end{array}$ \\
\hline
\end{tabular}




\begin{tabular}{|c|c|c|c|c|}
\hline 16 & $\begin{array}{c}\text { Cut end surface as } \\
\text { the drawings, } \\
\text { boring internal } \\
\text { hole } \varnothing 27, \emptyset 34.5 \text {, } \\
\varnothing 38, \text { margin of } \\
\text { the radius is } 0.2\end{array}$ & CAK6150D & $\begin{array}{l}90^{\circ} \text { facing } \\
\text { tool, inner } \\
\text { hole boring } \\
\text { tool }\end{array}$ & $\begin{array}{c}\text { Calipers, } \\
\text { Inside } \\
\text { Micrometer } \\
\text {, } \\
\text { Depth } \\
\text { Gauges }\end{array}$ \\
\hline 17 & $\begin{array}{c}\text { Turn round shaft, } \\
\text { cut end surface, } \\
\text { boring inner hole } \\
\varnothing 34, \emptyset 41.6, \emptyset 32, \\
\emptyset 27, \text { lathe inner } \\
\text { and external } \\
\text { thread, the margin } \\
\text { of the radius is } 0.2\end{array}$ & CAK6150D & $\begin{array}{l}90^{\circ} \text { facing } \\
\text { tool, inner } \\
\text { hole boring } \\
\text { tool, } \\
60^{\circ} \\
\text { threading } \\
\text { tool }\end{array}$ & $\begin{array}{c}\text { Length } \\
\text { Micrometer } \\
\text {, } \\
\text { Inside } \\
\text { Micrometer } \\
\text { Thread } \\
\text { Feeler }\end{array}$ \\
\hline 18 & Tempering & & & \\
\hline 19 & $\begin{array}{l}\text { Drill periphery } \\
\text { hole }\end{array}$ & Hass VF-3 & $\begin{array}{l}\text { center drill, } \\
\text { twist drill, } \\
\text { taps }\end{array}$ & Calipers \\
\hline 20 & $\begin{array}{l}\text { Mill key, drill } \\
\text { deep holes }\end{array}$ & JE80S & $\begin{array}{c}\text { vertical } \\
\text { mills, } \\
\text { center drill, } \\
\text { twist drill }\end{array}$ & Calipers \\
\hline 21 & $\begin{array}{c}\text { Nitriding } \\
\text { treatment, } \\
\text { protect threaded } \\
\text { hole and external } \\
\text { thread inside shaft } \\
\text { with bolt and } \\
\text { bulkhead }\end{array}$ & & & \\
\hline 22 & $\begin{array}{c}\text { Grinding end } \\
\text { surface as } \\
\text { drawings, } \\
\text { grinding outer } \\
\text { cylindrical } \varnothing 70, \\
\varnothing 82, \emptyset 58, \emptyset 56, \\
\varnothing 50 \text { as drawings } \\
\end{array}$ & $\begin{array}{c}\text { MK1632X1 } \\
000\end{array}$ & $\begin{array}{l}\text { Cylindrical } \\
\text { grinding } \\
\text { wheel A46 }\end{array}$ & $\begin{array}{l}\text { Length } \\
\text { Micrometer } \\
\text { Outside } \\
\text { Micrometer }\end{array}$ \\
\hline 23 & $\begin{array}{l}\text { Build center } \\
\text { frame, runout is } \\
0.01 \text {, grind all } \\
\text { inner hole as } \\
\text { requirements, } \\
\text { enlarged view of } \\
\mathrm{X} \text { segment, } \\
\text { margin is } 0.1\end{array}$ & $\begin{array}{l}\text { MGA1432 } \\
\text { X1500 }\end{array}$ & $\begin{array}{l}\text { Internal } \\
\text { Grinding } \\
\text { Wheel } \\
\text { WA46P }\end{array}$ & $\begin{array}{c}\text { Length } \\
\text { Micrometer } \\
\text { Inside } \\
\text { Micrometer } \\
\text {, } \\
\text { Depth } \\
\text { Gauge }\end{array}$ \\
\hline 24 & $\begin{array}{l}\text { Interface with the } \\
\text { shaft front end } \\
\text { surface, grinding } \\
\text { to the required } \\
\text { size 52js } 8\end{array}$ & $\begin{array}{c}\text { MGA1432 } \\
\text { X1500 }\end{array}$ & $\begin{array}{l}\text { Inner radius } \\
\text { grinding } \\
\text { wheel } \\
\text { WA46P }\end{array}$ & $\begin{array}{l}\text { 1: } 10 \text { Taper } \\
\text { Plug, } \\
\text { Shank, } \\
\text { Gages }\end{array}$ \\
\hline 25 & $\begin{array}{c}\text { Comprehensive } \\
\text { examination }\end{array}$ & & & \\
\hline 26 & $\begin{array}{l}\text { Clean, coated with } \\
\text { anti-rust oil, } \\
\text { storage }\end{array}$ & & & \\
\hline
\end{tabular}

\section{SHAFT ASSEMBLY BALANCING TEST}

For shaft parts, due to material uneven or blank defect, deviation generated by processing and assembly, even there are possible asymmetric geometry at design stage, etc., so that during the rotation of the shaft, the centrifugal force generated by each tiny particle can't balance each other, then cause vibration and noise effect. It will accelerate bearing wear and shorten the life of the machine. At severe cases it can cause devastating accidents [9]. Therefore, balancing test for the shaft and its assembly must be carried out, to reach allowed equilibrium accuracy and limit the mechanical vibration amplitude within the permissible range.

Balancing machine of the shaft consists of two V-shaped support frame, the axial stopper mechanism, corresponding sensors and power system. The base is the marble structure. As shown in Fig. 8, the shaft is placed on the two V-shaped support frame, adjust the opening width of the V-shaped bracket, and use a dial gauge to detect the runout of the shaft. At the same time, to reduce the resonance effects, the diameter of shaft support should be different with herein V-plus opening width.

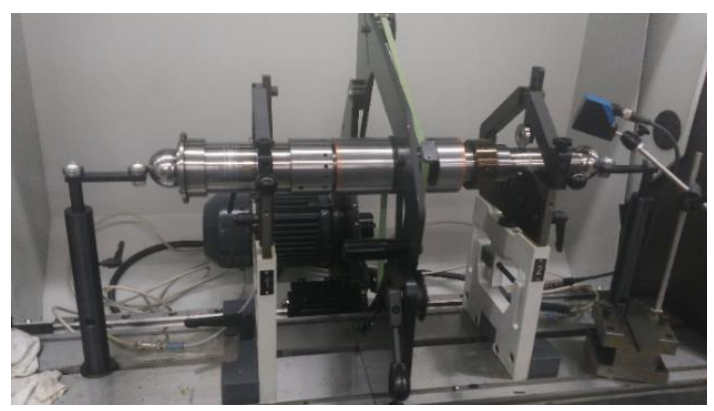

Fig. 8 Shaft balancing test

As shown Fig. 9, the balancing test of this project uses the supporting mode that two correction planes are placed on the middle of the supporting surface. Weight increasing is selected as calibration mode. The threaded hole of the shaft is screwed with a fastening screw to adjust dynamic unbalance, and the operating speed is chosen as 1200rpm according to spindle unit working speed. As shown in the Fig.9, dynamic unbalance of the shaft assembly are as following: $4.32 \mathrm{~g} \angle 62$ ${ }^{\circ}$ and $10.2 \mathrm{~g} \angle 157^{\circ}$.
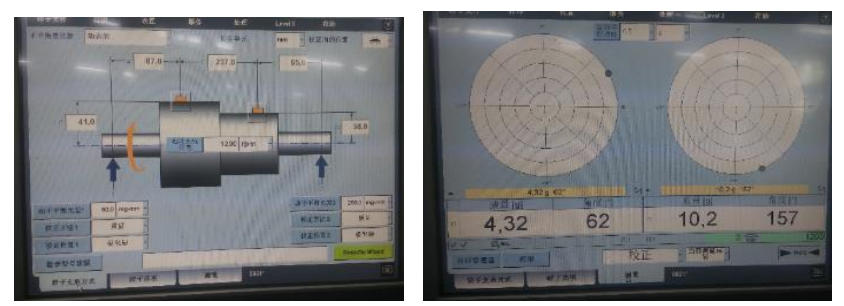

Fig. 9 Balancing parameter setting and measurement

According to GB/T9239--2006 "Mechanical vibration steady state (rigid) rotor balancing quality requirements":

$$
m=\frac{60 \times 1000 \times G M}{2 \pi n r}
$$

In the equation:

$M$ - rotor mass, $\mathrm{kg}$;

$G$ - accuracy class selection;

$R$ - correction radius, $\mathrm{r} / \mathrm{min}$;

$N$ - workpiece operating speed, $\mathrm{r} / \mathrm{min}$; 
$m$ - unbalance mass, g.

The balance accuracy class is determined as G0.4 level. The shaft is rigid rotor, the operating speed is $18000 \mathrm{r} / \mathrm{min}$, the assembly mass is $14.7 \mathrm{~kg}$, the correction radius is $40 \mathrm{~mm}$.

$$
m=\frac{60 \times 1000 \times 0.4 \times 14.7}{2 \pi \times 18000 \times 40}=0.769 \mathrm{~g}
$$

The allowable dynamic unbalances at the left and right ends are:

$$
m_{1}=m_{2}=\frac{m}{2}=0.3845
$$

The dynamic unbalance measurement data of the calibration process is shown at the table 3 .

TABLE 3 DYNAMIC UNBALANCE MEASUREMENT DATA TABLE

\begin{tabular}{|c|c|c|c|c|}
\hline & \multicolumn{2}{|c|}{ Left unbalance } & \multicolumn{2}{c|}{ Right unbalance } \\
\hline No. & $\begin{array}{c}\text { Mass } \\
(\mathrm{g})\end{array}$ & $\begin{array}{c}\text { Angel } \\
\left({ }^{\circ}\right)\end{array}$ & $\begin{array}{c}\text { Mass } \\
(\mathrm{g})\end{array}$ & Angle $\left(^{\circ}\right)$ \\
\hline 1 & 4.32 & 62 & 10.2 & 157 \\
\hline 2 & 2.61 & 303 & 1.79 & 199 \\
\hline 3 & 1.26 & 314 & 0.98 & 218 \\
\hline
\end{tabular}

\section{V.CONCLUSION}

The shaft is the core transmission part of the motorized spindle. Based on the mechanical performance requirements and assembly requirements with other parts, this paper did the structural analysis of the shaft, studied the blank chosen, processing steps, heat treatment technology and cutting tools

\section{REFERENCES}

[1] Weck M,Schumacher A. Machine tool for high speed machining. Proceedings of the International Seminar on Improving Machine Tool Performance, San Sebastian, 1988.

[2] Wu Y H. Motorized spindle unit technology of CNC Machine Tools. Science Press, 2005

[3] Chinese Mechanical Engineering Society Institute of Heat Treatment. Heat Treatment Handbook. China Machine press, 2013

[4] Lu J Z. Principle of Metal Cutting and Tools. China Machine Press, 2015

\begin{tabular}{|c|c|c|c|c|}
\hline 4 & 0.74 & 59 & 0.512 & 26 \\
\hline 5 & 0.348 & 111 & 0.999 & 2 \\
\hline 6 & 0.179 & 87 & 0.153 & 150 \\
\hline
\end{tabular}

As shown in Table 3 and Fig. 10, via the adding of set screws to the shaft, the dynamic unbalance of front and rear ends are $0.179 \mathrm{~g} \angle 87^{\circ}$ and $0.153 \mathrm{~g} \angle 150^{\circ}$, which satisfies the requirements.

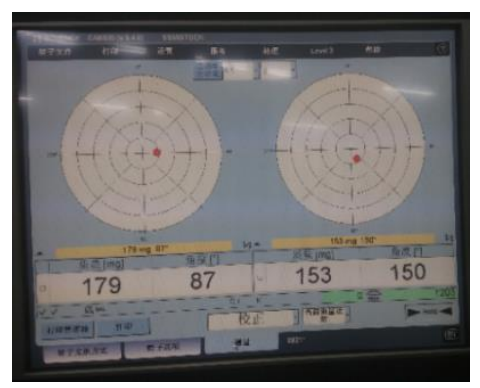

Fig. 10 Dynamic balancing correction results

selection, and summarized a set of efficient and feasible manufacturing processes. This manufacturing processes could be a reference for the domestic shaft processing. At the same time, the paper did the unbalance detection of shaft assembly at the dynamic balancing machine, then reduced the dynamic unbalance with adding weight.

[5] Harbin Institute of Technology etc. NC Tool Selection Guide. China machine press, 2014

[6] Josef D. Fachkunde M. Hunan Science \& Technology Press, 2007

[7] C. SteveSuh. Control of Cutting Vibration and Machining Instability. China machine press, 2015

[8] Wang X K etc. Machining Process Handbook. China machine press, 2007.

[9] Wang G A, Practical balancing technology for motor, China Petrochemical Press, 2012 